\title{
Effect of Systemic Soil Insecticides and a Plant Product on Microbial Load of Soil in Root (wilt) Affected Coconut Monocropping Ecosystem
}

\author{
By \\ Murali Gopal, Alka Gupta, P. Rajan and C.P. Radhakrishnan Nair ${ }^{1}$
}

\begin{abstract}
The changes undergoing in the microorganism population due to the application of phorate 10G, carbofuran 3G (@10 g a.i./ palm) and neem oil cake (@1.5 kg / palm) in the basin region of coconut growing in root (wilt) affected area was studied. Generally, a high microbial population was observed in the control plot. Carbofuran proved to be more toxic as compared to phorate as it suppressed the bacterial, actinomycetal, and free-living $\mathrm{N}_{2}$-fixer's number significantly. Against Nitrosomonas and Nitrobacter (nitrifiers), the influence was inconsistent. Neem oil cake enhanced bacterial and free-living $\mathrm{N}_{2}$-fixer count; against actinomycetes and fungi there was an initial stimulatory, and then antagonistic impact, whereas, it proved detrimental to the nitrifiers. From the six soil samplings done, spread over a period of six months, the microbial load was recorded to be high whenever there was moderate rainfall and medium temperature. Application of neem oil cake produced positive effect on the beneficial microorganisms as compared to the systemic insecticides.
\end{abstract}

\section{Introduction}

India stands first in the world in coconut production (APCC, Statistical Year Book, 1996) and approximately $50 \%$ is contributed by Kerala State. Yet the productivity level in this state is low, one of the major reasons being the prevalence of root (wilt) disease. This disease is caused by a phytoplasma (Solomon et al., 1983) which is carried by insect vectors Stephanitis typica and Proutista moesta (Mathen, et al., 1990). A study was undertaken to evaluate the effect of soil application of systemic granular insecticides and a natural plant product on vector control and its influence on regulation/incidence of root (wilt) disease on underplanted coconut seedlings in the diseased area. From the same experimental area, we collected soil samples to record the response of the soil microflora towards the insecticides and plant product. Exhaustive work had been done by Radha and Menon (1954), Rawther and Radha (1963), Potty (1977) and Thomas (1987), on the rhizosphere microflora in coconut monocropping and coconut based multi-storeyed cropping systems in root (wilt) affected area and similar work in root (wilt) free soils had been conducted by Nair and Subba Rao (1977), Ghai and Thomas (1989), Bopaiah and Shetty (1991) and Bopaiah (1994). However, this is the first attempt in describing the changes occurring in soil microflora in root (wilt) prevalent area as a consequence of application of carbofuran, phorate and neem oil cake.

To assess the effect of introduced pesticides, enumeration of microbial population like bacteria, actinomycetes and fungi is utmost important (Atlas, et.al., 1978). The nitrifying organisms are extremely sensitive to environmental changes. Therefore the nitrogen transformation is one of the most used parameters, to study the effect of agrochemicals (Parr, 1974).

We investigated the impact of phorate $10 \mathrm{G}$ (@10 g a.i. palm), carbofuran 3G (@ 10g a.i./ palm) and neem oil cake (@1.5 kg/ palm) on the number of bacteria, actinomycetes, fungi, free living nitrogen fixers and nitrifying bacteria Nitrosomonas and Nitrobacter, in the basin region of coconut palm.

\footnotetext{
${ }^{1}$ Central Plantation Crops Research Institute, Regional Station, Kayangulam, Krishnapuram, Kerala
} 


\section{Materials and Methods}

For the enumeration of the microflora, soil samples were collected from the coconut palm basin before the application of the pesticide during last week of December 1996 and on $3^{\text {rd }}, 15^{\text {th }}, 75^{\text {th }}$, $135^{\text {th }}$ and $180^{\text {th }}$ days after pesticides were applied on $23^{\text {rd }}$ January 1997. Generally, pesticide residues will occur in the top 6-8 inches of soil (Lichtenstein et al., 1962). This also is the region of greatest activity of soil flora and fauna (Alexander, 1961); thus, setting the stage for interaction of pesticides with soil life system. Using an auger, soil from top to a depth of $25 \mathrm{~cm}$ was collected from 3 spots of the basin. This was pooled, homogenised and air-dried. Collections were done from three palms at random from different replicates of each treatment. Soil samples were drawn from this material for the microbial count.

The population count of bacteria, actinomycetes, fungi and free-living nitrogen fixers was done by serial dilution technique (Nair and Subba Rao, 1977). One ml of 1:1,000,000 dilution for bacteria, 1:10,000 for fungi and actinomycetes and 1:1,000 for $\mathrm{N}_{2}$-fixers were plated. Five replications were done. The petri-plates were incubated at $28 \pm 2^{\circ} \mathrm{C}$ for $4-7$ days. Colonies developing on the agar medium were scored. Total counts of bacteria, actinomycetes, fungi and free living $\mathrm{N}_{2^{-}}$fixers were made on nutrient agar (Allen, 1959) Kenknights and Munaier agar (Allen, 1959), Martin's rose bengal agar (Martin, 1950) and Waksman medium 77, respectively. The results were expressed on a dry weight soil basis. The impact of the systemic insecticides and neem oil cake on the population of nitrifiers in the rhizosphere was determined by the most probable number (MPN) method of Alexander and Clark (1965). Ten grams of soil samples were taken from all the treatments and serially diluted up to $10^{-6}$ fold in sterile water. One ml aliquot was transferred from all dilutions to each of five test tubes containing $3 \mathrm{ml}$ of sterile ammonium calcium carbonate medium (for Nitrosomonas detection) and to a similar set of five test tubes containing nitrite calcium carbonate medium (for Nitrobacter detection). The tubes were incubated at $30 \pm 1^{\circ} \mathrm{C}$ for a period of 21 days. The presence of nitrite and nitrate was tested by the addition of three drops of Griess Illosvay's reagent. The test tubes which gave purplish red color were recorded as positive for Nitrosomonas (i.e. indicating the presence of nitrite). In case of Nitrobacter, tubes which failed to develop purplish red colour were recorded positive. Through a table of most probable numbers prepared by Cochran (1950), the population of the nitrifiers was computed using the positive results noted in the above experiment.

Analysis of variance for two way classification was followed for the analysis of data.

\section{Results}

The population of the bacteria reduced significantly in all the treatments after initial sampling and increased during the last sampling $\left(180^{\text {th }}\right.$ day), except in the case of carbofuran (Table 1). The beneficial effect of neem oil cake became apparent from the $135^{\text {th }}$ day onwards and the maximum bacterial count of $233.4 \times 10^{6} \mathrm{cfu} / \mathrm{g}$ dry soil was recorded on 180th day sample. Compared to control, neem oil cake improved the bacterial population; carbofuran proved toxic; whereas, phorate granules was neutral.

The total population of actinomycetes was stimulated by phorate and neem oil cake upto 75th day as compared to control (Table 2). Carbofuran again proved deleterious throughout the sampling period, with the lowest population being registered on $75^{\text {th }}$ day $\left(14 \times 10^{4} / \mathrm{g}\right.$ dry soil). Whereas, the highest number was recorded on 135th day in control (193.6 x 10 /g dry soil).

The fungal population was high 3 days after application of the pesticides and neem oil cake when compared to the control. The systemic insecticides suppressed the population from $135^{\text {th }}$ day with carbofuran being more intense. Neem oil cake had adverse effect on the fungi during $75^{\text {th }}$ day of the sampling (Table 3). Overall, there was no significant difference among the treatments. 
The count of free-living $\mathrm{N}_{2}$-fixers was enhanced significantly by the application of neem oil cake with maximum number being recorded on the 75 th day in this treatment $\left(180.2 \times 10^{3}\right)$. It is evident from Table 4 that ill effect of both the synthetic pesticides was maximum on $75^{\text {th }}$ day when compared to the control.

Nitrosomonas which acted in the first step of nitrification i.e. conversion of ammonium to nitrite $\left(\mathrm{NH}_{4}^{+}\right.$? $\left.\mathrm{NO}_{2}^{-}\right)$was observed to be very high during the last sampling from control plot (Table 5). A clear picture that emerged from this table is that synthetic pesticides improved the Nitrosomonas immediately after application, neem oil cake proved to be antagonistic. Nitrobacter which completed the nitrification in the second step by oxidizing nitrite to nitrate $\mathrm{NO}_{2}^{-}$? $\mathrm{NO}_{3}{ }^{-}$ ) was also inhibited by neem oil cake application as evident from Table 6 . The influence of phorate and carbofuran was also adverse but inconsistent when compared to control during respective sampling period.

\section{Discussion}

The initial sampling for this experiment was done during last week of December 1996. With copious rainfall up to November (Table 7) and application of $333+300+666 \mathrm{~g}$ of NPK during September-October 1996 the soil condition had been very favorable for healthy microbial activity as observed from the result data tables. From December 1996 onwards, the rainfall stopped to nil with increase in the maximum temperature (Table 7). These factors caused drying of the top soil resulting in lowered microbial activity during subsequent samplings. Fungal count was an exception which was observed to be high even during summer. The reason was the ability of the fungi to be present in dormant stage during unfavorable conditions (Alice et al., 1980). By the time the second last and last samples of soil were collected (during June/ July 97) the rainfall had started again providing sufficient moisture to improve the microflora population. This rainfall, temperature relationship with microbial activity was clearly observed in the results of control palms.

The bacterial count was much higher than any other type of microbe as this has the capacity to thrive vigorously on the root exudates (Alice et al., 1980). Among various treatments, carbofuran negatively influenced the bacteria in the basin region of coconut palm in root (wilt) affected area. Our results corroborated of Tu's (1972) wherein he found that 1 and 5 ppm carbofuran inhibited population of bacteria at $28^{\circ} \mathrm{C}$. Significant reduction in bacterial population was also reported by Oblisamy, et al. (1979) when carbofuran was applied at 1, 10 and $500 \mathrm{ppm}$ a.i. in sandy soil. Nimbalkar, et al., 1989 reported that phorate when applied at 1, 1.5 and $2 \mathrm{~kg}$ a.i./ ha for control of sucking pests in cotton reduced the population of bacteria initially but at harvest the number of microorganisms increased. Our study though carried out in an perennial plantation crop, also gave similar results when phorate was applied @ 10g a.i./ seedling in the basin region. In the case of neem oil cake treatment; the results showed improved bacterial population when compared to control. Our observation is supported by the report of Manibhushan et al., (1987) and Mukherjee et al., (1991) who found that bacterial number increased two fold on $60^{\text {th }}$ day over the $40^{\text {th }}$ day sampling.

Actinomycetes population was generally suppressed by carbofuran in the basin region of coconut palm throughout the experimental period except on the $15^{\text {th }}$ day sampling. But Mathur et.al., (1980) published that actinomycetes either increased or showed neutral response to carbofuran application in paddy fields. Varshney and Rana (1987) and Nimbalkar, etal.(1989) reported that phorate was non-deletirious towards actinomycetes as we had noticed the same in coconut monocroping ecosystem too. Rather there was stimulation in activity of actinomycetes during the initial stages. The interaction of neem oil cake with actinomycetes was positive up to $75^{\text {th }}$ day after which the number declined. Our results are comparable with the findings of Manibhushan et al. (1989) and Mukherjee et,al., (1991). Toxicity against fungal population by carbofuran and phorate had been reported by many workers (Kandaswamy et al. 1977; Singh and Prasad, 1979; Cowley and Lichtenstein, 1970) as we had recorded in our experiment. Neem oil cake had shown neutral effect towards the fungal population. Though carbofuran stimulates free-living $\mathrm{N}_{2}$-fixers in sandy-loam soil 
(Backman and clark, 1977), but we noted it to be detrimental to free -living $\mathrm{N}_{2}$-fixers in coconut palm basin. Phorate showed inconsistent stimulation and bacteriostatic effect on free-living $\mathrm{N}_{2}$-fixers, whereas such organophosphorus had been reported to be inhibiory to aerobic $\mathrm{N}_{2}$-fixing population (Sivasithamparam, 1970). Organically rich neem oil cake significantly improved the asymbiotic $\mathrm{N}_{2}$ fixers in coconut root basins. Similar observations had been made by Gopal (1995) in case of Azotobacter from sandy loam soil where $10 \%$ a.i. neem-based granule was applied @ 20kg ha. Eppler (1996) also made similar reports of useful microflora being stimulated by neem "actives" in soil.

Application of carbofuran and phorate had no adverse effect on nitrification by Nitrosomonas and Nitrobacter in this study. Such an observation was also reported by Ramakishna et al., (1978). Studies conducted by Patel and Desai (1985) also gave similar observations with organophosphorus pesticides. Neem oil cake showed significant suppression of both the chemoautotrophs which is in agreement with the observations of Mishra et al., (1975), Santhi et al., (1986) and Gopal (1995). It is also a well known fact that neem extracts are being used with urea prills as nitrification retarders (Waghray, 1997).

\section{Conclusion}

A very high microbial load had been observed by us in the basin region of coconut palm growing in heavily root (wilt) affected area. This observation is in consonance with the report of Potty (1977). The population of these microorganisms changes with fluctuation in the abiotic as well as biotic conditions. Our findings, in general, indicate that application of organically abundant neem oil cake improved the soil health by activating the beneficial soil microorganisms. The chemical pesticides showed some adverse effect with carbofuran being more severe than phorate.

\section{Acknowledgement}

The authors are grateful to the Director, CPCRI and The Head CPCRI (RS) Kayangulam for their encouragement. Thanks are also due to Mr. B. Anil kumar for his technical support during the investigation. 


\section{References}

1) Alexander M (1961) Introduction to Soil Microbiology, John Wiley and Sons Inc. New York.

2) Alexander M and Clark FE (1965) Method for most probable number of Nitrosomonas and Nitrobacter. Method of soil analysis. part 2, pp. 1477 - 1480.

3) Allen ON (1959) In Experiments in Soil Bacteriology. $3^{\text {rd }}$ edn. p.117.

4) Alice EJ, Karunakaran P and Samraj J (1980) A Comparative study of the rhizosphere microflora of coconut palms from diseased and healthy areas with reference to root (wilt). Indian Cocon.J. 11(2): 1-4.

5) Asian and Pacific Coconut Community (APCC) - Coconut Statistical Yearbook (1996) compiled by L. Tauffikkurahaman. pp 76.

6) Atlas RM, Pramer D and Bartha R (1978) Assessment of pesticide side effects on non target soil microorganisms. Soil Biol. Biochem. 10 : 231 - 239.

7) Backman PA and Clark EM (1977) Effect del carbofuran Y otros pesticides sobre las microrizas vericulos arbusculares del mani. Nematropica $7: 13$.

8) Bopaiah BM (1994) Beneficial microorganisms in the root region soils of coconut palm under different cropping systems - A Review. Cord X (1): 68 - 77.

9) Bopaiah BM and Shetty HS (1991) Soil microflora and biological activities in the rhizosphere and root region of coconut based multistoried cropping systems. Soil Biol. Biochem. 23 : 89 94.

10) Cochran WG (1950) Estimation of bacterial densities by means of "most probable number". Biometrics 6 : 105 - 116.

11) Cowley GT and Lichtenstein EP (1970) Growth inhibition of soil fungi by insecticides and annulment of inhibition of yeast extract or nitrogenous nutrients. J.Gen. Microbiol. 62 : 27 29.

12) Eppler A (1996) Bacteria. Seed kernel extracts. Bark extracts. Pure ingredients subheadings to chapter 3.2 in "The Neem Tree" (Ed. Schmutterer H) VCH Pubs.

13) Ghai SK and Thomas GV (1989) Occurrence of Azospirillum spp in coconut - based farming systems. Plant and Soil 114: 235 - 241.

14) Gopal, Murali (1995) Effect of fluchloralin and neem based granules on soil microbial activity. $\mathrm{PhD}$ Thesis, Indian Agricultural Research Institute (IARI), New Delhi.

15) Kandaswamy D, Marimuthu J, Oblisamy G and Subramanian TR (1977) Effect of application of insecticides on the HCN content and rhizospere microflora of sorghum crop. Madras Agr. J. $64: 302$ - 306 .

16) Lichtenstein EP, Mueller CH, Myrdal GR and Schulz KR (1962) Vertical distribution and persistence of insecticidal residues im soils as influenced by mode of application and a cover Crop. J. Econ. Entomol. 55 : 215. 
17) Manibhushan KR, Baby UI and Joe Y (1989) Effect of organic amendments on the saprophytic survival of the rice sheath blight pathogen and on the soil microflora. Oryza $26: 71$ - 78.

18) Martin JP (1950) Use of acid, rose bengal and streptomycin in the plate method for estimating soil fungi. Soil Sci. 69 : 215 - 232.

19) Mathen K, Rajan P, Nair CPR, Sasikala M, Gunasekaran M, Govindankutty MP and Soloman JJ (1990) Transmission of root (wilt) disease to coconut seedlings through, Stephanitis typica (Distant) (Heteroptera : Tingidae). Trop. Agric. 67 (1) : 69 - 73.

20) Mathur SP, Hamilton HA and Vrain TC (1980) Influence of some field applied nematicides on microflora and mineral nutrients in organic soil. J. Environ. Sci. Health, B 15 : 61 - 65

21) Mishra MM, Neelakantan S, Khandelwal KC, Bharadwaj SK and Vyas SR (1975) Margosa (neem) seed cake as an inhibitor of nitrification. Soil Biol Biochem. 7: 183 - 184.

22) Mukherjee B, Mitra S and Das AC (1991) Effect of oil cakes on changes in carbon, nitrogen and microbial populations in soil. J.Indian Soc. Soil Sci. 39 : 457 - 462.

23) Nair SK and Subba Rao NS (1977) Microbiology of the root region of coconut and cacao under mixed cropping. Plant and Soil 46 : 511 - 519.

24) Nimbalkar SA, Pawar SN, Toley YM and Lanjewar RD (1989) Effect of granular systemic insecticides on soil microorganisms when applied to control sucking pests on cotton H.4 Magazine, College of Agriculture, Nagpur, India. 56 - 59 : 21 - 24.

25) Oblisamy G, Natarajan $T$ and Bagyarai DJ (1979). Effect of carbofuran on certain microbiological and chemical properties of red soil. Mysore J. Agric. Sci. 13 : 187 - 190.

26) Parr JF (1974) In "Pesticides in soil and water" (Ed. Guenzi WD). Soil Sci. Am. Madison, Wisconsin. pp. 315 - 340.

27) Patel BV and Desai SG (1985) Effect of insecticides on nitrification and ammonification activity in soil. Indian J. Microbiol. 25 : 26-28

28) Potty VP (1977) Rhizosphere microflora of coconut palm (Cocos nucifera L.) in relation to root (wilt) disease. PhD thesis, University of Kerala, Trivandrum, India.

29) Radha K and Menon KPV (1954) Studies on the root (wilt) disease of coconut palm. A comparative study of the rhizosphere microflora of coconut from diseased and healthy trees. Indian Cocon. J. 7: 99 - 106.

30) Ramakrishna C, Rao VR and Sethunathan N (1978) Nitrification in simulated oxidized surface of a flooded soil amended with carbofuran. Soil Biol. Biochem. 10 : 555 - 556.

31) Rawther TSS and Radha K (1963) Studies on the seasonal variations in the rhizosphere microflora of coconut with special reference to fungi. Proc. First Conf. Cocon. Res. Workers. Trivandrum, India. pp. 298 - 305.

32) Santhi SR, Palaniappan SP and Purushottaman D (1986) Influence of neem leaf on nitrification in a lowland rice soil. Plant and Soil. 93 : 133 - 135.

33) Singh I and Prasad SK (1979) Influence of pesticides on rhizosphere and microbial population of mung and wheat crops. Indian J. Nematol. $8: 102-109$. 
34) Sivasithamparam K (1970) Some effects of an insecticide dursban and weedicide linuron on the microflora of a submerged soil. The Riso $19: 339$.

35) Solomon JJ, Govindankutty MP and Neinhaus F (1983) Association of mycoplasma-like organisms with the coconut root (wilt) disease in India. Z. Pflkrankh. Pflschutz. 90 : 295 - 297.

36) Thomas GV (1987) Microbial population, enzyme activity, and VA mycorrhiza in the root region of coconut in relation to in situ green manuring. Proc. Placrosym $6: 267$ - 274.

37) TU CM (1972) Effect of four nematicides on activities of microorganisms in soil. Appl. Microbiol. 23 : 398 - 401.

38) Varshney V and Rana RS (1987) Studies on the effect of phorate, disyston and carbofuran on soil microflora of tarai soils. Pesticides 21 (4) : 37 - 42.

39) Waghray P Ashok (1997) Neem's Potential in Fertilizer Nitrogen Efficiency Improvement. Global Neem Update (Qtrly. Newsletter) 11 (2) : 8 - 10. 
Table 1: Effect of systemic insecticides and plant product on bacterial population in coconut basin ( $\mathrm{n} \times 10^{6} \mathrm{CFU} / \mathrm{g}$ dry soil) (Average of 5 replications)

\begin{tabular}{|c|c|c|c|c|c|c|c|}
\hline \multirow{2}{*}{ Treatment } & \multicolumn{6}{|c|}{ Day of sampling } & \multirow{2}{*}{ Mean } \\
\hline & 0 & 3 & 15 & 75 & 135 & 180 & \\
\hline Control & 176.2 & 7.2 & 3.8 & 19.0 & 64.2 & 200.2 & 78.4 \\
\hline Phorate & 274.4 & 31.6 & 4.4 & 4.4 & 13.0 & 163.0 & 81.8 \\
\hline Carbofuran & 170.0 & 20.0 & 5.4 & 3.4 & 5.2 & 52.0 & 42.6 \\
\hline Neem oil cake & 220.4 & 32.8 & 3.0 & 11.2 & 188.2 & 233.4 & 114.6 \\
\hline Mean & 210.2 & 22.9 & 4.1 & 9.5 & 67.6 & 162.1 & \\
\hline
\end{tabular}

CD for treatment: 22.6, CD for day of sampling: $27.7, \mathrm{CD}$ for interactions: 55.4

Table 2: Effect of systemic insecticides and plant product on actinomycetes population in coconut basin (n x 10 ${ }^{4} \mathrm{CFU} / \mathrm{g}$ dry soil) (Average of 5 replications)

\begin{tabular}{|c|c|c|c|c|c|c|c|}
\hline \multirow{2}{*}{ Treatment } & \multicolumn{6}{|c|}{ Day of sampling } & \multirow{2}{*}{ Mean } \\
\hline & 0 & 3 & 15 & 75 & 135 & 180 & \\
\hline Control & 120.6 & 27.8 & 28.4 & 33.8 & 193.6 & 149.2 & 92.2 \\
\hline Phorate & 152.4 & 32.2 & 46.2 & 36.4 & 55.2 & 55.4 & 62.8 \\
\hline Carbofuran & 116.0 & 20.8 & 38.4 & 14.4 & 48.0 & 42.8 & 46.7 \\
\hline Neem oil cake & 82.2 & 48.2 & 118.8 & 88.2 & 62.2 & 445.6 & 74.2 \\
\hline Mean & 117.8 & 32.2 & 57.9 & 43.2 & 89.7 & 73.2 & \\
\hline
\end{tabular}

CD for treatment: 12.8, CD for day of sampling: 15.7, CD for interactions: 31.4

Table 3: Effect of systemic insecticides and plant product on fungal population in coconut basin ( $\mathrm{n} \times 10^{4} \mathrm{CFU} / \mathrm{g}$ dry soil) (Average of 5 replications)

\begin{tabular}{|c|c|c|c|c|c|c|c|}
\hline \multirow{2}{*}{ Treatment } & \multicolumn{6}{|c|}{ Day of sampling } & \multirow{2}{*}{ Mean } \\
\hline & 0 & 3 & 15 & 75 & 135 & 180 & \\
\hline Control & 7.0 & 19.0 & 2.8 & 15.0 & 11.4 & 12.2 & \\
\hline Phorate & 8.2 & 17.6 & 7.6 & 16.0 & 8.0 & 9.4 & \\
\hline Carbofuran & 9.4 & 15.2 & 6.2 & 6.8 & 7.4 & 8.0 & \\
\hline Neem oil cake & 11.8 & 13.4 & 8.0 & 8.4 & 12.8 & 13.2 & \\
\hline Mean & 9.1 & 16.3 & 6.1 & 11.5 & 9.9 & 10.7 & \\
\hline
\end{tabular}

CD for Treatment : N.S, CD for day of sampling : 2.6, CD for interactions : 5.2 
Table 4: Effect of systemic insecticides and plant product on free living $\mathbf{N}_{2}$ fixer population in coconut basin ( $\mathrm{n} \times 10^{3} \mathrm{CFU} / \mathrm{g}$ dry soil) (Average of 5 replications)

\begin{tabular}{|c|c|c|c|c|c|c|c|}
\hline \multirow{2}{*}{ Treatment } & \multicolumn{6}{|c|}{ Day of sampling } & \multirow{2}{*}{ Mean } \\
\hline & 0 & 3 & 15 & 75 & 135 & 180 & \\
\hline Control & 70.6 & 25.0 & 36.4 & 42.6 & 44.8 & 55.6 & 45.8 \\
\hline Phorate & 116.0 & 19.8 & 41.6 & 16.2 & 38.4 & 28.8 & 43.4 \\
\hline Carbofuran & 53.6 & 18.2 & 40.8 & 18.0 & 46.4 & 24.0 & 33.5 \\
\hline Neem oil cake & 104.4 & 51.2 & 178.8 & 180.2 & 106.8 & 107.8 & 121.5 \\
\hline Mean & 86.1 & 28.5 & 74.4 & 64.2 & 59.1 & 54.0 & \\
\hline
\end{tabular}

CD for treatment: 7.9, CD for day of sampling: 2.6, CD for interactions: 19.3

Table 5: Effect of systemic insecticides and plant product on Nitrosomonas population in coconut basin ( $\mathrm{n} \times 10^{3} / \mathrm{g}$ dry soil) (results of 10 fold dilution with 5 tubes per dilution)

\begin{tabular}{|c|c|c|c|c|c|c|c|}
\hline \multirow{2}{*}{ Treatment } & \multicolumn{6}{|c|}{ Day of sampling } & \multirow{2}{*}{ Mean } \\
\hline & 0 & 3 & 15 & 75 & 135 & 180 & \\
\hline Control & 28.0 & 33.0 & 40.0 & 11.0 & 13.3 & 18.0 & 23.8 \\
\hline Phorate & 22.0 & 30.0 & 13.0 & 14.0 & 7.9 & 7.0 & 15.6 \\
\hline Carbofuran & 95.0 & 17.0 & 11.0 & 7.0 & 9.5 & 2.2 & 23.6 \\
\hline Neem oil cake & 22.0 & 1.7 & 1.4 & 7.9 & 2.2 & 7.0 & 7.0 \\
\hline Mean & 41.7 & 20.4 & 16.3 & 9.9 & 8.2 & 8.5 & \\
\hline
\end{tabular}

CD: Non - Significant

Table 6: Effect of systemic insecticides and plant product on Nitrobacter population in coconut basin (n $\times 10^{3} / \mathrm{g}$ dry soil) (results of 10 fold dilution with 5 tubes per dilution)

\begin{tabular}{|c|c|c|c|c|c|c|c|}
\hline \multirow{2}{*}{ Treatment } & \multicolumn{6}{|c|}{ Day of sampling } & \multirow{2}{*}{ Mean } \\
\hline & 0 & 3 & 15 & 75 & 135 & 180 & \\
\hline Control & 22.0 & 25.0 & 32.0 & 12.0 & 14.0 & 9.5 & 19.0 \\
\hline Phorate & 33.0 & 31.0 & 59.0 & 12.0 & 14.0 & 1.1 & 25.0 \\
\hline Carbofuran & 17.0 & 43.0 & 35.0 & 2.7 & 1.7 & 3.8 & 17.2 \\
\hline Neem oil cake & 13. & 6.1 & 2.8 & 3.0 & 2.4 & 5.2 & 5.4 \\
\hline Mean & 21.25 & 26.2 & 32.2 & 7.4 & 8.0 & 4.9 & \\
\hline
\end{tabular}

CD : Non - Significant 
Table 7: Rainfall, Temperature and Relative Humidity (RH) Chart

\begin{tabular}{|l|l|c|c|c|c|}
\hline \multirow{3}{*}{ Year } & \multicolumn{1}{|c|}{ Month } & \multicolumn{2}{|c|}{ Temperature $\left({ }^{\mathrm{O}} \mathrm{C}\right)$} & \multirow{2}{*}{ RH $(\%)$} & $\begin{array}{c}\text { Rainfall } \\
(\mathrm{mm})\end{array}$ \\
\cline { 3 - 4 } 1996 & Max. & Min. & & 358.1 \\
& July & 30.3 & 23.5 & 95 & 123.2 \\
& August & 29.9 & 23.3 & 95 & 261.1 \\
& September & 29.9 & 23.5 & 95 & 266.2 \\
& October & 30.9 & 22.9 & 95 & 153.4 \\
& November & 31.5 & 22.9 & 95 & 58.5 \\
\hline \multirow{3}{*}{1997} & December & 31.9 & 21.2 & 94 & 0.0 \\
& January & 33.3 & 20.5 & 92 & 4.9 \\
& February & 33.4 & 21.9 & 92 & 47.9 \\
& March & 34.2 & 23.5 & 91 & 109.8 \\
& April & 33.8 & 23.7 & 93 & 84.3 \\
& May & 33.1 & 24.1 & 93 & 551.6 \\
& June & 31.8 & 23.5 & 93 & 579.6 \\
\hline
\end{tabular}

